\title{
Chaebol Investments and Government Policy
}

\author{
ELGENE YLN"
}

It is argued that one key reason behind Korea's stalling economic growth is the lack of sufficient investments in facilities, especially by the chutelosl companics. The government charges the chacbuls with under-investingr and has puc considerable pressure on them to invest more aggressively. Sine once main pathological fearume of the chaehols has been their propensicy to over-invest, this paper exarnines whether there las been a change in thatelol bethivior. Evidence shwws that chachols are not under-investing in facilities. The chatebols are engaging in investments that make husiness sunse; even chough these levels of investment may fill short of what the goretminent would like to see. By miseresting the true situation. the grovernment may be initiatingr a complex $p$ xower garne: with the chaebols, which will prove of be counecr-presductive.

Keyayrils: chaebsl investment in facilities, production capaciay utilization rates, under-investmene, Presidene Roth's chisebol policy, Korean ecusunic reforms

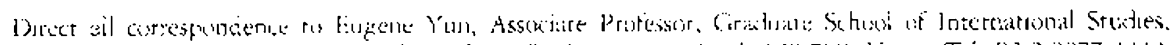

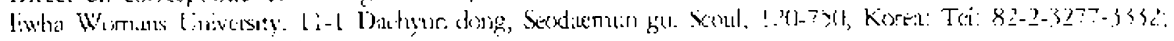

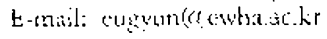




\section{INTRODI'T'TION}

K oreat has a love-hate relationship with the chacbols. The part of Korea that loves the chacbols does so because alung with the zovernment, the chiebols played a cucial role in proxtexing the spectacular conomic grownth and develup. ment during the four decades following the Korean War. These days, the chactool companies form the bedtuck of the Korean economy and there is wide recognition that the nation's international comprtitiveness in global markets will unost likely come from their ranks (sec "Mission $\$ 20,000 \% "$ by Boston Consulting Group and Maej] Kyungie Shınmun). The special government concessions given to Samsung and LC, waising the tran on bulding large production facilirics in the Scoul area, are manifestations of this belict. Morcorer, any fecling toward the chacbols is easily mingnificd because the livelihosed of the average Korean is heavily dependent on them. The 30 largest cornglomerates collectively account for nearly half of all sales and over $15 \%$ of GDP in value inded terms.

Whether true or not, the notion that the future success of the Kurean cconomy is inextricably cied co the success of the chaetbols is a bittcr pill 10 swallow. This is beciuse the chatebol system is perceived os concain serinus flaws. Onc of the carlicst works that cxaminte the chatbol problem is by Jones and Sakong (1980). Since then, substantial research has gont into understanding the historical pattern of chacbol behavior, (sce Chang 2003), while other studics have cxplored the roots or causes of the chactul problem (So 1994). The 14y? financial crisis gave chatbol rescerch a new impctus with strong stmplasis being placed the suthect of corporate governance (see Lee 20013) and restructuring (see Lee 2000 and Aho 2001).

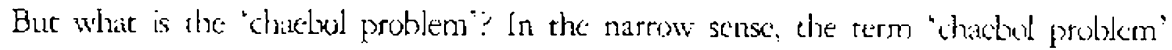
refers $t$ t) the excessive concentration of ownership of economic resources, the oligropelistic: nzarket structure in which the dhactuls thrive, and the presess in which chatebols

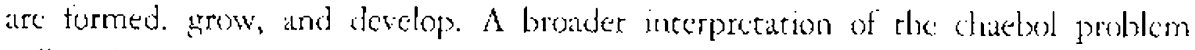
will include anti-chaebol senciment. This scudy does not deal with the subject of unci-chaelod sentiment por sc; but will stick to the narrower defintition of the chatbot problem as describut by Chang and Park (2000). According to them, the chatebol prohlem consists of low prufitability, high financial leverage, abnormal ownership structure: a peculiat ancede of financing, and excessive diversification.

Using data from other countries in different points in time and utilizing muleiple measurement ctiteria for understanding the chacbol features viewed als pathological in nature, Chang and Park prowide a refreshing view of the chactol problem. They conclude that the so-called problems are atl basically toon-problems. They find that "there is no clear evidence that Korean corporite protitability is exceprionally low by international standards." Similarly, they believe the pre-crisis debt-equity ratio in Korein (between 300\% and 350\%) wo be acceptable and not exceptionally high by intermational standards. Thus, they do not think that the higl, debt-exuity ratio 
should be held responsible for bringing atoust the financial crisis.

Chang and Park defend the cross-holding structure of the chacbol companites on the grounds that it is a way for chacbols to multiply their funds available for investing "by creating ficritious capital on the basis of which new shares could be issued." On the related topic of high reliance on debe financing while avoiding equity frnancing, Chang and Park claim that this is only part of the story. As they see it, the Korean chachols were aggersive fundraisers in the equity market and if debr finascing secmed (1) loom so large; is is because "they found eren these large sums ratised in the stock market insuffeciene for the agcressive investment strategy they had adopted." As it rums out, the "octespus tentactes" strategy, or the pursuir of excessive diversintation, is also not such a serious problem. Despite the large number of subsicliaries, for mose chacbuls, two to four core companics generate over $70 \%$ of all group sales. Chang and Park believe, therefore, that the chacbols are quite focused.

What, then, is the real chactexl problene' (hang and Park redefine the real chachol problem to be two things: 1) their strong tendency to over-invest; and 2) the abuse of their ever-growing political power. Perversely, cursent conventional wistom letieves that one key reason behind Koreat's stalling economic growth engine is the lack of sufficient investments in Facilities, or under-inestment, especially by the chaebol companies. The gravernment laas fexusud on this under-investmont theme and hats put ansiderable pressuri on the chachols to invest more ageressively. Sol far, the chachols have responded with words and promises mly.

The purpose of this study is to assess the government policy pertaniug to chacbul investmene. Presiktent Rols Mex) Hyun's government bas rejeatedly linked Korea's recale pour conomic perfirnatace to the slowdown in denxestic demand. Within domestic demand, facilitics inxestment has become a focal point of governmene effores to resrose Korcais GDP growth rate back to a respectable level (e. w. in excess of

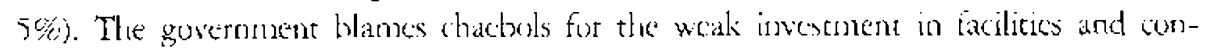
sequently the low level of demestix demant.

It is nor pussible to asserst uith any precision the exact contribution of thatbol (defined as the 30 largest. For eximple) investments in toral facilitiks investment. On the other hand, according to Jwa (2003), becwesn 1985 and 1995, the 30 largest chaebols account for for to $16 \%$ of assets in all industries (excluding finatucial and insurance industries). This lends creternce to the icka that the chactols play an important role in facilities investmen and conscequently, fovernmese effors to raiss: the pace of conomic growth has focused on chakbol invesment activitics. Although it would be lighly desiable to make a carctul appraisal of the contritution of chactols es rotal facilitics invesement, the present study will follow conventional wisdom on the notion of chatbols playing an important and stable role in deremining ahe level of facilitics investment. It should be pointed ent that this simplifying assumption allows us ro treat facilitics invesoment and chacbol investment as two objects which 
move in a highly correlated manner.

The remainder of this paper is urganized as follows. In Section 2, we explore some key macroconomic data and show, contraty to government charges, that the chathols are not under-investing. Sections 3 and 1 discuss the implications of not under-investing and how this situation affects governmenc policy, In Section 5, we consider che upen conflic berween the government and chachols and suggest how the complexity of this conilict should change if the government were to ikcept that idea that the chactors are not under-investing. Consluding remarks are given in Section 6.

\section{INVESTMENT' AND CONVENIIONAL WISDOM IN KOREA}

()er-investment has been at longstanding problem in Korea (see for exanple Jwa 2003\%. Indeed, so chronic was the prothlem that ower the last three decades, the

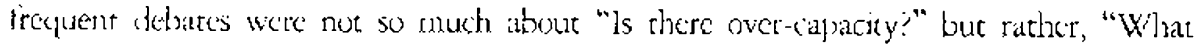
can wi do about it?" (cmbentional wistom believed (correctly) in the cristence of over-celpacity. Toulay, business is in a prolenged slump, the unemploynent rate among

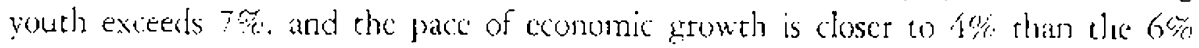
predicted in carly $20(1)$ by the government. Pruducer and consuneter sentiments are extrencely poor.

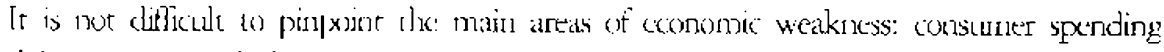
and investment in tiacilites. Consumet spending took a crippling bluw after the sperding binge acconplatyeng the nini-ecunomic ecbound of $20(12$. The number of indivistuals

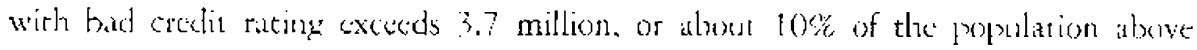
age 15. Furchermore, with household debt in excess of $\mathrm{KRW}$ 150 rrillion troughly ISSD 450 billion), w $6(\%)$ of GDP, lendars ate now erying to reduce their exposure to houscholds. However much Korta would like es sce a sharp recovery in consuner sperneling, short of resorting to sorne drastic measures (which, incidentally, are never the counted ust), the connomy is likely to be strek with this unusually low spending rate for the foresceable future. Tle grovernment know's dlis and is consecfuenty paying greater atcention to the other problem areas: investment in facilitics, or what todidy's cuntentional wistom would call "under-investment."

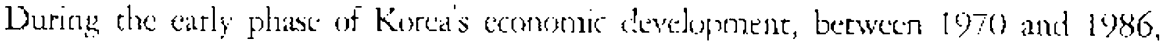
Korca's invesment in facilities averaged $7.4 \%$ of GDP. The Korean economy texk of in the rnid 1980s and facilieses itvestment averaged $12.8 \%$ of GDP between 198? and loy6. The conomic recession that followed the financial crisis of 199: had a najer impace on facilities investmene. As can be seen in Table 1, there was at heary drop in facilities inestment, with year-over-year growth rate plummeting to $-41.1 \%$ in $101098,-48.4 \%$ in $2 Q 1 \% 98,-45.1 \%$ in 301998 , and $-33.1 \%$ in 1Q1998. The fall in investments can be appreciated from a different perspective: facilities investment as a perecentage of GDP for thesc four quarters is very low, rangingr berwen? $? .8 \%$ and $9.3 \%$ 
TABLE 1. GROWTH RAIE (\%) OF FXPENDITIILLS OF GDP

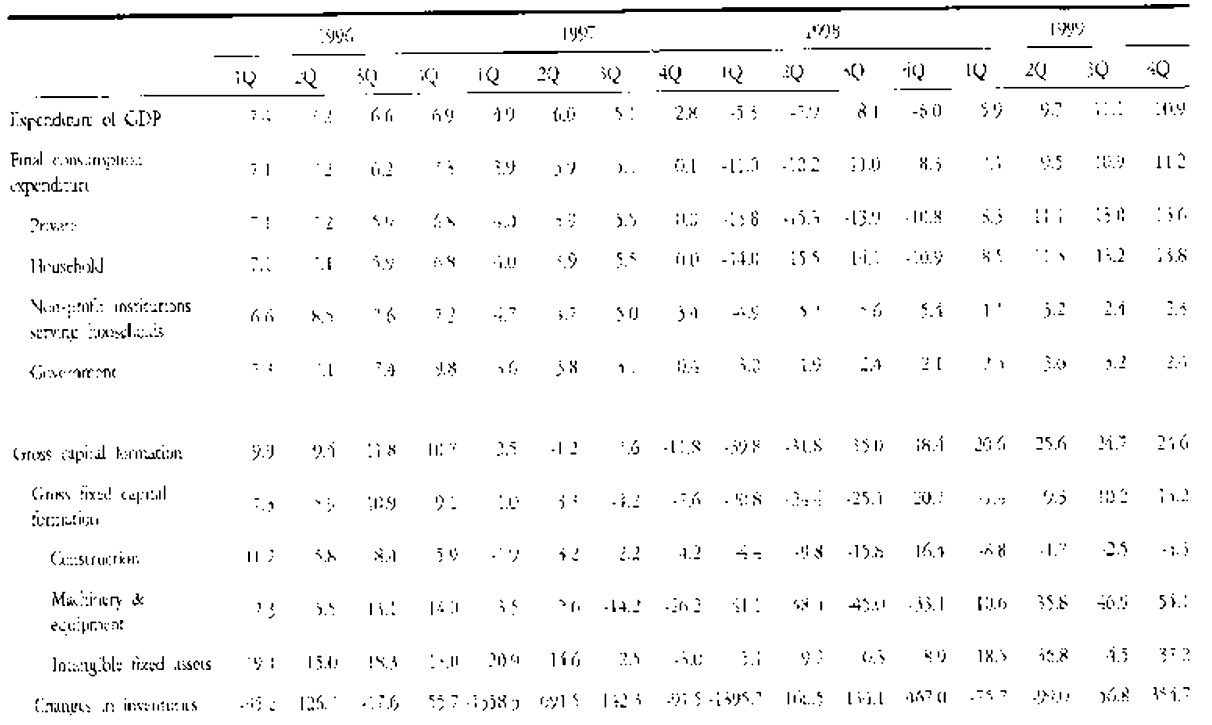

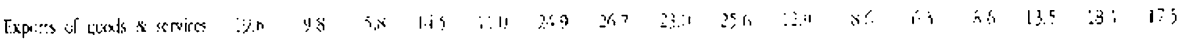

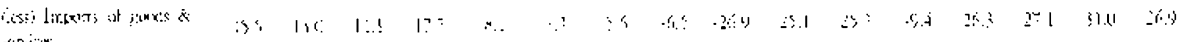
xrices

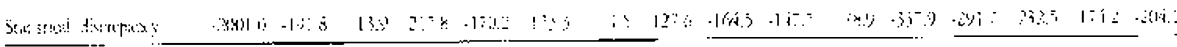

\begin{tabular}{|c|c|c|c|c|c|c|c|c|c|c|c|c|c|c|c|c|c|c|c|}
\hline & & $I: x$ & & & & ו וה & & & & $3 x$ & & & & Sh: & & & & 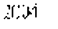 & \\
\hline & $\mathrm{iQQ}$ & 24 & () & (t) & :(1) & - & $: Q$ & 1() & i! & - V & 30 & 18 & 10 & $2 Q$ & 30 & $1 Q$ & I & -Qv & $\therefore Q$ \\
\hline Expet:d:t:ıx uf (ill? & 131 & 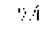 & $\therefore$ & $\vdots \vdots$ & $\because ५$ & $\therefore$ & $i, i$ & gr: & $\therefore 9$ & $\because: i$ & $\therefore x$ & $\because 5$ & : : & $\therefore$ & ? - & $\therefore . ?$ & Si & $\because:$ & 6 \\
\hline 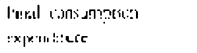 & it: ; & 8. & $s \mathrm{~s}$ & $1: \vdots$ & 2.2 & $n^{\prime}$ & i : & $\because$ & $\because 1$ & 13 & $\because$ & 5 & $\therefore:$ & -11 & 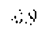 & 1.1 & bin & $11 i$ & $\therefore$. \\
\hline Privite & i $1 ;$ & $11: 2$ & $\because$ & is & $2 !$ & $i i$ & sis & $\because \because$ & y... & H.? & $\div 8$ & 5 & $\hat{1 !}:$ & 1.8 & $\therefore \%$ & -2.2 & $\therefore 1$ & ito & i) \\
\hline H:andust & $\because$, & $: 0 . \div$ & $\therefore$ & $1 \leq$ & $\therefore 1:$ & $i . i$ & $3 . i$ & $\therefore$ & 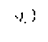 & 5 & $\because$ & $\$$ & $1:-$ & 13 & $.1: 1$ & -11 & $\therefore$ & 11.9 & $\therefore 8$ \\
\hline 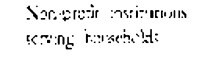 & $\therefore \dot{B}$ & I. & $1 \ddot{7}$ & $11 r_{1}$ & \}: & 4 & $1 . i$ & $\vdots$ & -9 & $\because \because y$ & : & $i$. & i! & 16 : & "5 & $i \ddot{c}$ & 11 & 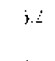 & $i$. \\
\hline (a.verathe & $\therefore$ & $?$ & $::$ & $\therefore$ & $i:$ & $;: \dot{x}$ & $\therefore$ & $\Leftrightarrow \therefore$ & $\because$ & $\because:$ & 5 & f. - : & i! & $3=$ & $\vdots j$ & 3 & 2.4 & $i \vdots$ & భ \\
\hline
\end{tabular}

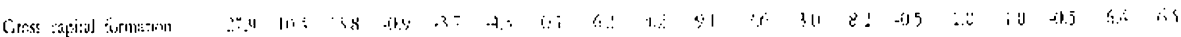

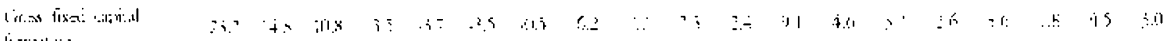
i:j:1.11.1:1

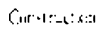

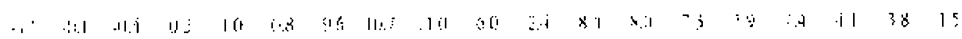

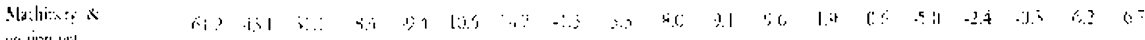

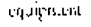

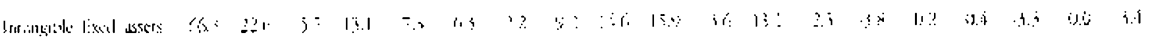

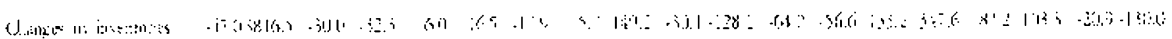

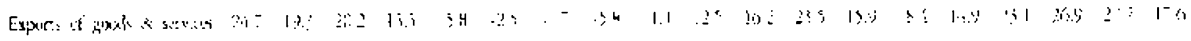

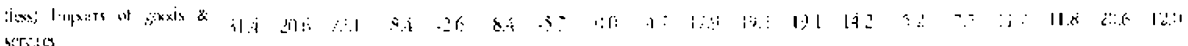




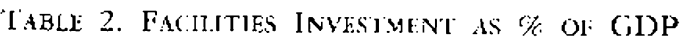

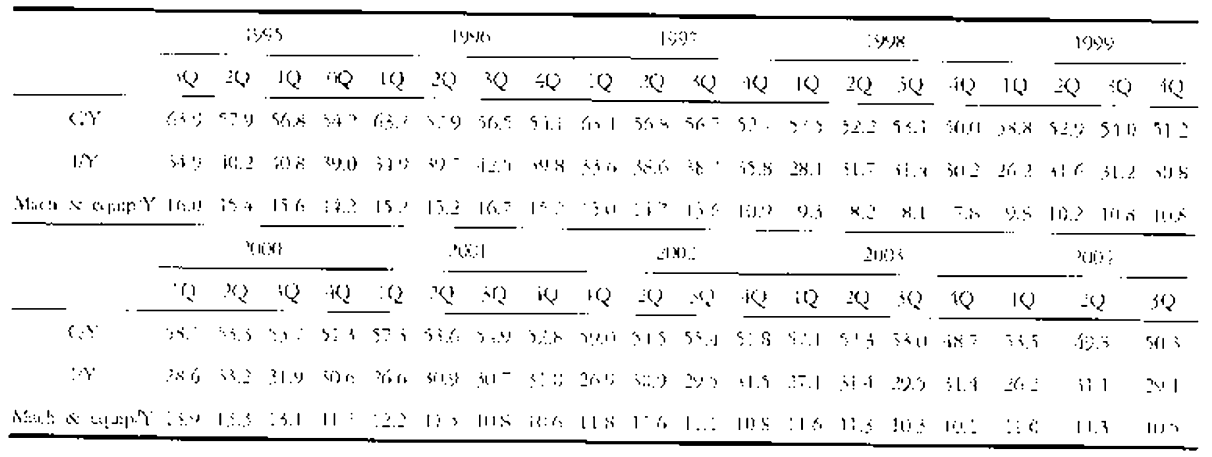

One rcmarkable Kurcan aclieverment, for which President Kim Dac Jung and his government like to take credit, is the sjeced of economic recovery from the financial crisis. It is hard to put an exact date on when the financial crisis "ended," but by the 3Q1999, the GDP growth rate was up to $11.1 \%$ (albeit off a low base the previous yearl and facilities investment as a percentage of (il)P was back up into double digits at $10.8 \%$. Incidentally, facilities investment as a percentuge of GDP reached is high of $13.9 \%$ in 1Q2000, and has nor dropped below $10 \%$ since 2 Q1999.

FITIRE I. FACILITES INTFSTMENT, 1970 200)

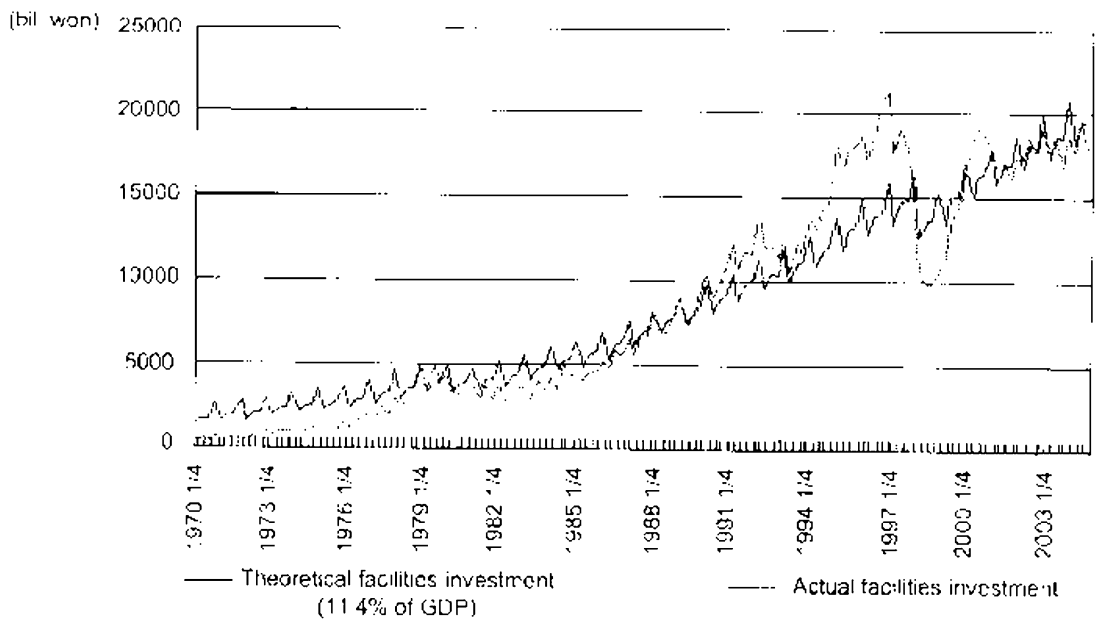

X) M:RER, KOSIS

Based on the data on facilities investmene as a percentage of GDP sinc 3Q1999, it is difficule to conclude that Koret is suffering from under-investment. To be surc, the numbers consistently are a cad (one or two percentage points) lower than the $12.8 \%$ ayerage berween 1987 and $19 \% 6$. However, it is worth kecping in mind that $12.8 \%$ is a troublesome hendhmark because this number cones from a period 
in time when the Koxean coonomy was over-investing. Viewed in anothet way', investment in lacilities as a percentage of cibp for the 20 years leading up to the financial crisis averaged $11.4 \%$. İ̈rure I graphs acrual facilities investment as a percentage of GDP and compares this againse the 20 -year benchmark average of $11.4 \%$.

Consider some effects of investing in tacilities. If for some resson there is over-investment, ther the phenomenon should strow up as excessise excess production capacity. In other words, since some slack in the production capacity is desirable or optimal, over-invesment will endarge the size of the slakeness. The best way to discem excessiveness is to obscrve changes in the facilities operation urilization rates. Over-investment should result in lower capacity urilization rates. Conversely, if there is under-investment, then one would expect to obscreve higher capacity utilization rates.

Tigure 2 depices production capacity utilization rates since 1980 . Between 1987 and 1996 , the capaciry utilization rate averaged $79.4 \%$, ranging from 7 . 0 \% to 82.0\%. Aggregate demand fell bxarase of the financial crisis and the capacity urilization rate foll shaply to $68.1 \%$ in 1998 . Ithe ensuing economic recovery was accompanied by a rebound in the utilizarion rate; the utilizarion rate measured $76.5 \%$ in 1999. $78.6 \%$ in $2000,75.3 \%$ in $2001,78.4 \%$ in 2002 , and $78.3 \%$ in 2003 . All of these numbers are below the $79 \%$ average recorded during the over-investment years (between 1987 and 1996). Io tox surc, mest recently since Octoher 2005; the utilization rate has moved above the $79.4 \%$ level going to a high of $83.1 \%$ in February 2004 . However, the rate has drophed sharply since then and has hovered berween $78.8 \%$ and $81.8 \%$

The data from production capacity utilination rates cherefore appear to support the asscrtion that the recent levels of facilities investmene in Korca are not excessively low and should not be labeled as "under-investeneme."

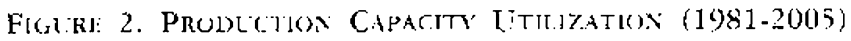

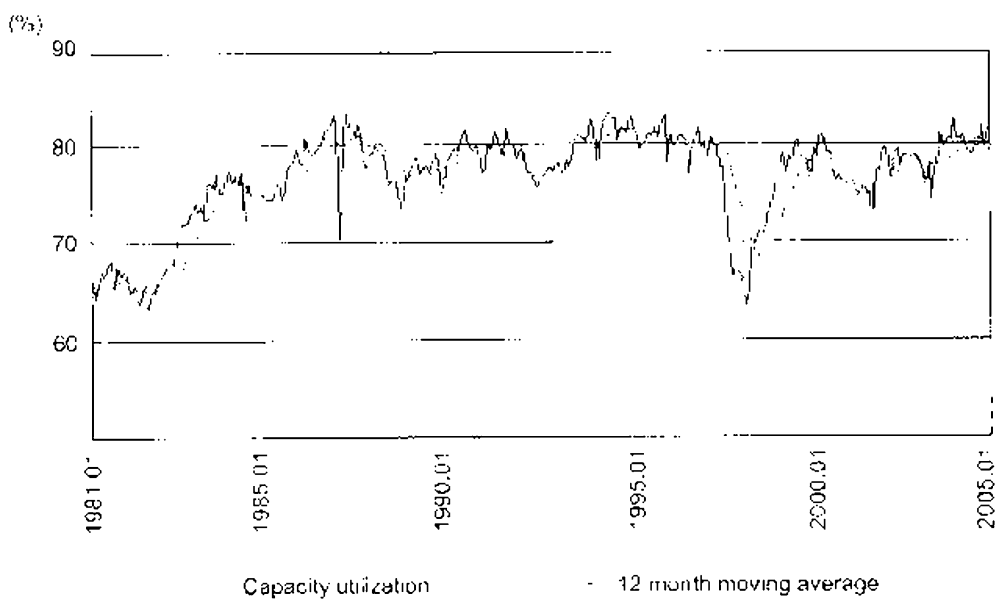

Sol:R(I:: Kosis 


\section{THE PROBIEM OF NOT UNDER-INVESTING}

Followers of the conventional wistom will be surprised to learn that Korea is not under-investing. This is because local media has given ample news coverage of the economic slowdown together with the slowdown in investments and consumer spetxding. On top of this, President Roh Moo I Iyun and his surnior policy makers lave added to the sense of drarnat and desperation by publicly asking the chachols to increase investments.

S) what is really going on? linder-investing cakes plate when the level of invescment falls below sume optimal amount. This praper has argued that the investment behavior in Kurea in recent years does not deviate sufficiently far from the investments seen during the gomgo days of 1987 to 1996 , when the chachols were prone to over-invest. It may be true that the chacbols are not investing as aggressively as in the years leading up to the financial crisis in 199? but this dows not mean that the chacbols are now under-investing.

If the Korean economy is not under-investing, then the investment bellavior must be either optinal or excessive. If this is the crue situation, then some important implications may be drawn.

First, economic recovery will be tirther away in the future thatn orherwise. The economy is in a vicious circle: stower conomic growth lowers capacity utilization aates, which then lowers the need to invest, which in turn contributcs toward slowing econorric growth further. Second, the grovernment should re-consider what motiwates the chacbols. In particular, the chaebols are not being uncooperative in an arrempe to threaten the new government. The chactols are not playing a complicated game with the groverninent, but are simply investing at levels they believe are suitable giver the current market conditions and future outlook for the econsmy.

Ihird, aftempts by the government co artificially raisc investment may boost cconomic growth temporarily, but will eventually lower growth over the long cerm. Ieft alone, the tendeney should the tor the conony to idjust the investmene levels to rempove excess capacity. Government interference will exacerbatc the problem of exress capacity, rendering the government action counter-productive. Fousth, the grovernment should rcvisit its chacthol policy.

\section{POLICY IMPLICATIONS}

The government is dearly not happy with the current low levels of investment. Cufortunately, government displeasure does nor justify cilling these Ievels of investment "under-invesring." On the contrary, it is persible to conjecture that the decision-rnakers in charge of investments are responding optirnally to poor economic conditions and a bleak tuture outlook. It should also be noted that past investment decisions atfece today's production capacity, as well as capacity utilization. 
Frustrated with the continuing scagnation in investments, the government shows signs of wanting to resurt to strong-arm tactics co torce the chacbols into investing more aggressively. (For example, before President Roh hosted a dinner hosted at the Blue House on May 25, 2004, the chackol invitees all announced plans to increase 2004 investments by roughly $30 \%$, collectively.) Upon further reflection, however. it is easy to sec that pushing the chaebols more decply into over-investment bethavior is a bad ides and may be dangerous, since it may add to the speed and duration of an cononic downtum in the future.

In gencral, investment decisions today affect future production capacity. When the investment cycle has run irs proper course downward, production capacity will once again be in short supply and the economy will embark on the upward slopings part of the investment cycle. 'I'his happens quite naturally, without active government involventent in more marure conomies. In the case of Koreal, the difficult lessons about natural investment cycles and the required optimal investment decisions are just being learned. having just gone through a painful financial crisis. The government should realize that the chactsols are extracting the right matket signals, probably for the firse time collecrively, and making well-informed investment decisions. Consequently, a becter course of action will be to wait patiently for the economy to ges through the investment cycle.

It is conceivable that an activist economic policymaker may want to intervene in the investment cycle by encouraging under-investing as a way to shorten the time taken to reath the bottom of the cycle. This secms all right theoretically, but to cngincer such a forced economic slowdown may not be practical policically. Morenver, since the Korean economy has little or no experience with aggregate under-investment, the policymakers will be uperating in unchared territory.

The above arguments should not be misconstrued. In particular, the governmene should not think that it must not be pro-active on matters concerning investments. Since investrnent decisions coday are in function of the conomic condition and the outlook for the future, the government may attempe to change marke conditions (e.g., interest rates, guvernment spendiug) and outhok (e.g. kJ'As, improvement in cronomic and systemic infrastructure).

Finally, the goverument will do well to avoid being impiticht. Contrary to conventional wisdom, the economy is not under-investings. This means that cconomic recovery is farther away in the future than had the conomy been under-investing.

\section{PRESIDENT ROH'S CHAEBOL POIICY}

In the 2002 presidential rare. Mr. Roh Moo Hyun ran an effective elecrinn canpaign that emphasized reform and reansparcncy. As President. Mr. Roh has thrown his polirical weighe behind efforts ro reform Korean polities. It is seill too early to say whether policical reforms are headed in the righe direction and go far conough. What 
Presidene Roh has clone, however, is set the wheels of polirical reform in motion.

How alsout the wheels of conomic reform? Sadly, these appear to be stuck. When Presictent Roh first stepped into the Blue House in February 2002, he promised to carry out reforms throughout the course of his five-year presidency. It comes as a surprisc, therefore to see so litte action on the economic front.

On retlection, there wete some good opportunities. The SK Global scandal, the credit card crunch, corporitte slush funds for politicians and unruly labor disputes, are lust a few of the opportanities that lame knexking, but which rhe growernment failed to exploit. The President also brietly flired with two mini visions, the "Noreh Fast Asian Hub" and "20,000 dollar inconc," but cuuckly put them in the backburuter. On the policy frond, freguene surveys show cmphatically that no economic policy has managed to impress the gencral public.

As a result, the economy is in an anticipatory mode. Each day without action only heightens the sense of anticipation. This, of course, is had and has unpleasant cronomic conscquences. Take for example what happens with investments. The oyde of "no action, grcater anticipatrion" raiscs the level of uncertainty, which in rurn, negatively affects investment decisions.

President Roh and his goveroment should be nore ransparent on the question of econonic reforms. If there is some new vision for the economy, then this vision should be carefully spelled out. Similarly, if there is a plan for chacbol reform, then these plans shoukd be circulated. This is eertainly cotsistent with the earliet Presidential promise of transparency.

What if there is non new vision for the economy and no plan for chichol reform? Odd as this question may somil, it may not he that far removed from the truth. And if there is no vision and no plan at this time, this fact shoukd be made known. Oher than sulfer some mimor embarrassment for not being fully prepared, the damage would be segligible. The payoff: on the other hand, will be the removal of some fundanental uncertainty hanging over the economy.

\section{CONCLLIDING REMARKS}

Korea roday is at an important crossroads. After three decades of robust economic gerowth. Korcas growth engine appears to be moving somewhat sluggishly. Confidence is in short supply and many conomists believe that Korea is in a crisis.

bocil commentutors find much reason to form a pessinoisric economic outlook. These include, among other things, increasing competition from China, decreasing aggregate dcmand, tising inflation, and declining long run fotential GDP growth rare. Behind these concerns, however, lies a more fundamennal problen. The government-chabol partnership, long thought to have been a coucial element of Kurea"s spectacular economic growth, appears to be in a statc of thux.

the governmenc is untappy with the chaebsis for not investing nore angressively. 
They have asked repearedly for greater "cooperation," but thus far, the chaebols have only paid some lip service and have taken no discernable action. On the flip side, the charbols are also unhappy with the government. '1hey fexl that the government is coercing them into making adtditional investments whose business merits are cuestionable. Having experienced the financial crisis, each chacbol knows that to over-invest is dangerous and that any business failure will be its responsibility.

Conventional wisclom is on the side of the government and belicves that Koreat is under-investing in facilities. Thus paper has argued that Korea is oot under-investing in facilities and that the goternment should not inisread or mistepresent the true situation. The clacbols arc probably engaging in investments that make business sernse. And even bough these levelis of investment may foll slore of what the government would like to set: the government should not interpret their behavior as threatening or challenging.

A complex power game between the grovernmest and the chathols could well be counterproductive. In some respects, the gane is alfeady cending toward an unhappy equilibrium because of the findamental uncerainty brought about by a lack of economic vision from the new President and his government. There is no question that the chatebls fear and anricijate some sort of government batcklash against their economic power. If the governonent has a coherent chacbol policy, it should be released the public seoncy tather than later. On the ocher hand, if there is no such chacbol policy, then that fact should also be made known to the public. If nothing else, at least this admission will clear some bad air.

\section{REFERNCES}

Ahn. Choong-Yong. 2001. linancial and Corporatr. Sector Restructuring in South

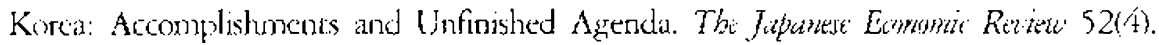

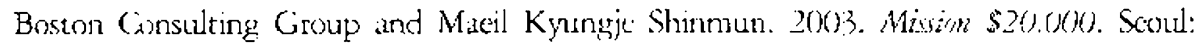
Macil Kyungie: Shinnum Press.

Chang. Ha Jexn and Park Hong-Juc. 2000. An Mternative Perspecive on Goremment Policy eowards the Chatbol in Korta: Industrial Policy, Financial Rogulations, and

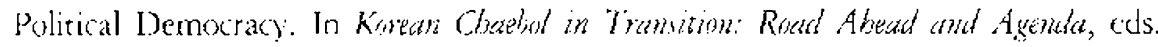
Sung Hec Jwa and In Kwon Iee. Scoul: Korea Fconomic Research Institure.

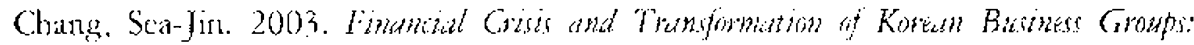
The Ribe and Fall of Clateloth. Cambridge Crniversity Press.

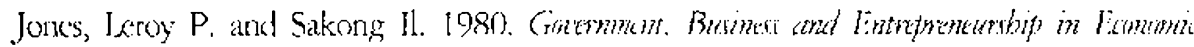
Detelophent: The Korain Case. Carobridger MA: Harvard University Press.

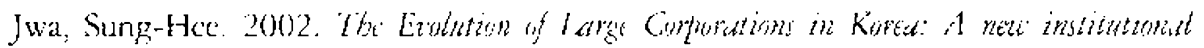

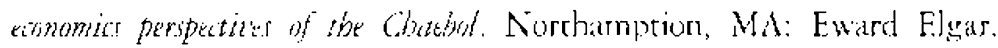

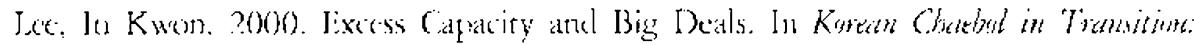

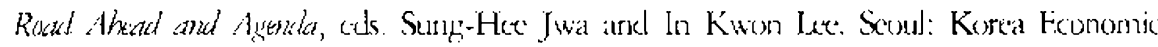


Restarch Insticute.

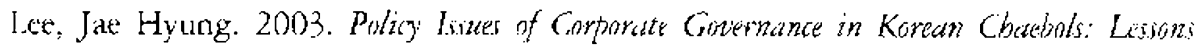
from the Japuntse Experiente. Senul: Kored Development Institure.

Lec, Jac Woo. 2000. Chaebol Restructuring Revisited: A Coasian Perspective. In

Korvan Chaphnt in Transition: Road Abead and Agenda, cds. Sung-Hee Jwa and lo

Kwon Lcc. Scoul: Knrea Economic Research Institute.

So, Byung-hee. 1991. The Iiffect of Industrial Policy and Rent-Secking on Chaebol

Growth. Korat Policy Stuly Report 3. 